\title{
Response of Mycorrhizal and P-Fertilized Soybeans to Nodulation by Bradyrhizobium or Ammonium Nitrate ${ }^{1}$
}

\author{
R. S. Pacovsky, E. A. Paul, and G. J. Bethlenfalvay²
}

\begin{abstract}
Management of $\mathrm{N}_{\mathbf{Y}}$-fixing bacteria or P-scavenging endomycorrhizae may lead to decreased fertilizer use on extensivelycropped lands. To measure the effectiveness of these microsymbionts, soybean [Glycine $\max$ (L.) Merr. cv. Amsoy 71] plants were grown in a growth chamber in a soil [Josephine silty clay loam (mesic Typic Haploxerult)] low in plant-available $\mathbf{N}$ and P. Plants were inoculated with different Bradyrhizobium strains or received nutrient solutions of different $N$ concentrations $(0.0$, $1.0,2.0,4.0 \mathrm{mM} \mathrm{N}$ ) and $P$ adequate for maximum plant growth under these conditions. Other plants were infected with a vesicular-arbuscular mycorrhizal (VAM) fungus and a Bradyrhizobium strain and received no $N$ or $P$ in the nutrient solution. The purpose of this study was to determine the growth response of soybean to $\mathbf{N}$ fertilization or nodulation by $B$. japonicum under conditions of high $P$ availability or VAM-assisted $P$ uptake. Nodulated non-VAM soybean plants had dry weights and development similar to that of the $4.0 \mathrm{mM} N$ fertilizer treatment. Total $N$ and $M n$, leaf area, and leaf $P$ of nodulated plants were higher than in the comparable $\mathbf{N}$-fertilized plants in the absence of $P$ stress. Soybeans infected with both the VAM fungus and Bradyrhizobium were similar in total dry weight, leaf area, and development to plants that received 1.0 or $2.0 \mathrm{mM} \mathrm{N}$. They, however, contained more leaf $\mathrm{N}$, more root $\mathrm{Cu}$ and $\mathrm{Zn}$, and less $M n$ and $P$ than the $2.0 \mathrm{mM} N$ treatment. It is concluded that a number of host characteristics of nodulated plants are due to the altered functional aspects of the symbiosis and not $\mathbf{N}$ input alone. The presence of the VAM fungus can decrease nutrient stress in environments limited in $\mathrm{P}, \mathrm{Zn}$ and $\mathrm{Cu}$, elements essential in $\mathbf{N}_{\mathbf{2}}$ fixation.
\end{abstract}

Additional index words: Glomus, $\mathbf{N}$ nutrition, Nodule activity, Root nodule.
Eguminous crop plants form mutualistic associations with the bacterium Bradyrhizobium and with vesicular-arbuscular mycorrhizal (VAM) fungi (9). In soils marginal in $N$ and $P$, these microsymbionts play a crucial role in legume development and yield (29) since enhanced nodulation and $\mathrm{N}_{2}$ fixation result from improved $P$ nutrition (8). Under conditions where $P$ is plentiful but $N$ is not, improved growth and nutrition of nodulated legumes depends on the effectiveness (19) of symbiotic $\mathrm{N}_{2}$ fixation. Nodulated hosts are usually compared to $\mathrm{N}$-deficient, non-inoculated controls to assess $\mathrm{N}$ input over the lifetime of the symbiotic association (22) or to nonnodulating, near-isogenic lines (6). For studies involving metabolic processes in $\mathrm{N}_{2}$-fixing associations, non-inoculated plants must be given fertilizer $\mathrm{N}$ to provide controls that are morphologically and nutritionally similar (15). Plants grown with $\mathrm{NH}_{4} \mathrm{NO}_{3}$ under a saturating $\mathrm{P}$ regime (23) permitted observation of developmental characteristics as a function of $\mathrm{N}$ nutrition alone. These observations formed the baseline for comparisons of individual levels of $\mathrm{N}$ application with Bradyrhizobium ("slow-growing" Rhi-

\footnotetext{
${ }^{1}$ Contributed by the Western Regional Research Center, USDAARS, Albany, CA 947 I0 (R.S.P. and G.J.B.), in collaboration with the Dep. of Plant and Soil Biology, Univ. of California, Berkeley, CA 94720 (E.A.P.).

${ }_{2}$ Microbiologist, professor, and supervisory plant physiologist, respectively. Requests for reprints should be sent to G.J. Bethlenfalvay.
} 
zobium) effects in the presence or absence of a VAM fungus. While such controls grown on $\mathrm{NH}_{4} \mathrm{NO}_{3}$ may be equivalent to Bradyrhizobium-inoculated plants in some morphological or nutritional characteristics, they will not be physiologically equivalent (28).

When $\mathbf{P}$ and $\mathbf{N}$ are limiting, normal host-plant growth depends on $P$ uptake assisted by a VAM fungus (30), efficient $\mathrm{N}_{2}$ fixation even under $P$ stress (7), and microsymbiont compatibility (20). Synergistic effects between a VAM fungus, such as Glomus fasciculatum, and Bradyrhizobium with respect to $\mathrm{N}_{2}$ fixation and mycorrhizal colonization (27) have led to improved host productivity, $\mathrm{N}$ and $\mathrm{P}$ nutrition, and nodule formation (30). These latter effects increase photosynthesis (32) which, in turn, stimulates nodule and VAM activity $(3,16)$ in an auto-catalytic cycle. Micronutrients essential in nodulation and $\mathrm{N}_{2}$ fixation (31) are often increased by mycorrhizal colonization. Hormonal effects, triggered by the presence of either symbiont $(1,26)$ may also contribute to the effectiveness of the tripartite symbiosis.

The purpose of this study was to determine the growth response of soybean to $\mathrm{N}$ fertilization or nodulation by different strains of $B$. japonicum under conditions of high $P$ availability or $P$ uptake mediated by a VAM fungus at low levels of available $P$.

\section{MATERIALS AND METHODS}

\section{Experimental Design}

Plants were subjected to two $\mathrm{P}$ regimes by providing $\mathrm{P}$ through either phosphate fertilizer or a VAM fungus to facilitate $P$ uptake. Nitrogen was provided for non-VAM plants by nutrient solutions containing one of four different $\mathrm{NH}_{4} \mathrm{NO}_{3}$ concentrations or the plants were inoculated with one of three strains of Bradyrhizobium. Plants colonized by VAM received no $\mathrm{NH}_{4} \mathrm{NO}_{3}$ and were either inoculated with the same $B$. japonicum strains as the non-VAM plants or were not inoculated. Thus, there were seven $\mathrm{N}$ treatments under the $\mathrm{P}$ fertilizer regime and four $\mathrm{N}$ treatments among VAM plants. There were six replications of each treatment in a randomized-block design for a total of 66 plants.

\section{Biological Materials}

Soybean [Glycine max (L) Merr. cv. Amsoy 71] seeds (0.5 to $0.6 \mathrm{~g}$ ) were surface sterilized and planted as described elsewhere (23). Plants were inoculated with one of three B. japonicum strains $(110,136$, or $61 \mathrm{~A} 118$, originally obtained from H.H. Keyser, USDA-ARS, Beltsville, MD 20705), or with the Gerdemann isolate of $G$. fasciculatum (Thaxt. sensu Gerd.) Gerd. and Trappe, or with bothGlomus and Bradyrhizobium. Plants that received the VAM fungus were inoculated with $60 \times 10^{3} \mathrm{~mm}^{3}$ of Josephine soil containing between 300 and 350 spores of a $G$. fasciculatum isolate originally obtained from Abbott Laboratories (Long Grove, IL 60047). ${ }^{3}$

\section{Nutrient Solutions}

Plants colonized with the VAM fungus were furnished with a basal ( $\mathrm{N}$ - and $\mathrm{P}$-free) solution which consisted of 1.5

\footnotetext{
${ }^{3}$ Reference to a company and/or product by USDA is only for the purposes of information and does not imply approval or recommendation of the products to the exclusion of others which are also suitable.
}

$\mathrm{mMCaCl}, 0.5 \mathrm{mM} \mathrm{K}_{2} \mathrm{SO}_{4}, 0.25 \mathrm{mMMgSO}, 25 \mu M \mathrm{H}_{3} \mathrm{BO}_{3}$, $20 \mu M$ FeEDDHA, $2.0 \mu M \mathrm{ZnSO}_{4}, 0.5 \mu M \mathrm{CuSO}_{4}, 0.4 \mu M$ $\mathrm{H}_{2} \mathrm{MoO}_{4}$, and $0.6 \mu M \mathrm{CoCl}_{2}$. Plants not inoculated with the VAM fungus or Bradyrhizobium received solutions containing $\mathrm{N}$ as either $0.0,0.5,1.0$, or $2.0 \mathrm{mM} \mathrm{NH} \mathrm{NO}_{3}$ and $\mathrm{P}$ as $1.0 \mathrm{mM} \mathrm{KH} \mathrm{KO}_{4}$. Plants inoculated with $B$. japonicum only received the $\mathrm{N}$-free solution. The $\mathrm{pH}$ of all fertilizer solutions was adjusted to 6.9 with $0.01 \mathrm{~N} \mathrm{KOH}$. Pots were watered to field capacity three to five times a week with the nutrient solutions.

\section{Soil}

The soil used was a Josephine silty clay loam (mesic Typic Haploxerult). It contained, per g of soil, $12.8 \mu \mathrm{g} \mathrm{NH}_{3}^{+}-\mathrm{N}$, $4.5 \mu \mathrm{g} \mathrm{NO}--\mathrm{N}, 1.6 \mathrm{mg}$ Kjedahl $\mathrm{N}, 4 \mu \mathrm{g}$ Olsen-available $\mathrm{P}$, $0.33 \mathrm{mg}$ total $\mathrm{P}$, and it retained $0.95 \mathrm{~g} \mathrm{P} \mathrm{g}^{-1} \mathrm{P}$ added. Soil was sterilized with ethylene oxide and limed $\left(10 \mathrm{~g} \mathrm{CaCO}_{3}\right.$ $\mathrm{kg}^{-1}$ soil) as described previously (23). Soil $\mathrm{pH}$ after liming was 7.0 (1:5 $\mathrm{CaCl}_{2}$ extract). Each pot received $1.25 \mathrm{~kg}$ of soil which was initially watered with a leachate of the VAM inoculum filtered free of VAM propagules so as to establish the same microflora in VAM and control treatments.

\section{Growth Conditions}

Plants were grown in a walk-in style growth chamber (Sherer Model 511-38). The light/dark period was 16/8 $\mathrm{h}$ and temperature and relative humidity were $28 / 22^{\circ} \mathrm{C}$ and $70 / 80 \%$, respectively. Photosynthetic photon flux density varied from 650 to $550 \mu \mathrm{mol} \mathrm{m} \mathrm{m}^{-2} \mathrm{~s}^{-1}$ from the center to the edge of the growth platform. Plants were rotated within a block three times a week to minimize positional effects. The platform grating and growth chamber floor were disinfected once a week with $0.70 \mathrm{~L} \mathrm{~L}^{-1}$ ethanol to reduce cross-contamination by Bradyrhizobium strains.

\section{Evaluations and Assays}

All plants were harvested 9 weeks after planting. In all cases this time corresponded to the full bloom stage for soybeans. Nodule activity (24) of excised roots (ATP-dependent $\mathrm{H}_{2}$ production and $\mathrm{C}_{2} \mathrm{H}_{2}$ reduction) was determined by gas chromatography following two 30 -min incubations ( $\mathrm{H}_{2}$ evolution and $\mathrm{C}_{2} \mathrm{H}_{2}$ reduction) of excised roots as described previously (22). Leaf areas were determined using a Li-Cor L-1500 leaf area meter (Lincoln, NE 68504). Leaf number and leaf area were measured separately for primary (main stem) and secondary (lateral branch) leaves. Leaf, stem, root, and nodule weights were measured after drying for 2 days at $70^{\circ} \mathrm{C}$. Plant analysis for N (Kjeldahl), $\mathbf{P}$ (perchloric acid digest) and micronutrients (dry ashing and atomic adsorption spectrophotometry) were determined by standard methods (23). Percent colonization of the host-plant root system was established histologically by staining the mycorrhiza with trypan blue and scoring the roots (4). The chitin content of $20 \mathrm{mg}$ of VAM roots was determined spectrophotometrically, and the fungal biomass was estimated as described in a companion article (23). An analysis of variance (ANOVA) was performed on the plant and soil data for the P-fertilized, non-VAM soybeans. Regression analyses were carried out on data from the $\mathrm{NH}_{4} \mathrm{NO}_{3}$-supplemented treatments to determine plant response as a function of $\mathrm{N}$ input. Differences to nodulation by Bradyrhizobium strains were evaluated using Duncan's Multiple Range Test (DMRT). The procedures of the Statistical Analysis Systems were used in all evaluations (2). Data for plant growth as a function of soluble $\mathrm{N}$ concentration were used to generate response curves. Means and variances for data of nodulated plants were projected onto 
these curves to determine the equivalent $\mathrm{N}$ input and to establish confidence intervals for comparison of nodulated hosts with $\mathrm{N}$-fertilized plants. A separate ANOVA was performed on data from VAM-colonized soybeans, and a comparison between different treatments was carried out using DMRT. A third ANOVA was run on data from all nodulated treatments along with DMRT to assess the impact $P$ source had on $\mathrm{N}_{2}$ fixation.

\section{RESULTS \\ Dry Weight}

In the case of $\mathrm{N}$ fertilized soybeans, dry weight increased linearly with increasing $\mathrm{NH}_{4} \mathrm{NO}_{3}$ concentrations (Table 1) for leaf $\left(\mathrm{y}=2.0 \mathrm{x}+6.1, r^{2}=0.99\right.$; $\mathrm{p}<0.01)$ stem $\left(\mathrm{y}=2.3 \mathrm{x}+5.8, r^{2}=0.98, \mathrm{p}<\right.$ $0.01)$ and root $\left(y=0.8 x+5.6, r^{2}=0.96, p<0.01\right)$. Non-VAM plants inoculated with $B$. japonicum strains were $60 \%$ to $100 \%$ larger than plants receiving no $\mathrm{NH}_{4} \mathrm{NO}_{3}$ (-N control). Soybeans infected with $\mathrm{Bra}$ dyrhizobium only had stem and leaf dry weights equivalent to plants that received between 3.0 and $4.0 \mathrm{mM}$ $\mathrm{N}$, while root growth was equivalent to plants given from 2.0 to $3.0 \mathrm{mMN}$. Strains 136 and $61 \mathrm{~A} 118$ were more efficient than strain 110 at promoting dry weight increases (Table 1). Plants inoculated with strain 136 had significantly $(p<0.05)$ larger shoot to root ratios than the $4.0 \mathrm{mM} \mathrm{N}$ treatment regardless of the source of P. Dry weights of nodulated VAM plants were 50 to $60 \%$ greater than those of the non-nodulated VAM control (Table 1). However, nodulated VAM plants were generally only two-thirds as large as plants from the P-fertilized set inoculated with the same Bradyrhizobium strain.

\section{Developmental Stage and Leaf Area}

Soybeans inoculated with Bradyrhizobium had as many nodes as the $4.0 \mathrm{mM} \mathrm{N}$-fertilized plants (Table 1). Nodulated VAM-plants had fewer nodes than nodulated plants given soluble $P$. Total leaf area increased linearly with $\mathrm{N}$ fertilization $(\mathrm{y}=575 \mathrm{x}+692$, $\left.r^{2}=0.93, \mathrm{p}<0.01\right)$ as did primary leaf area $(\mathrm{y}=$ $\left.240 \mathrm{x}+964, r^{2}=0.94, \mathrm{p}<0.01\right)$ and secondary leaf area $\left(y=334 x-2.8, r^{2}=0.92, p<0.01\right)$. The total leaf area of nodulated plants was equivalent to plants receiving between 3.8 and $4.5 \mathrm{mM} \mathrm{N}$. Nodulated VAM soybeans had $50 \%$ the total leaf area of P-fertilized, nodulated plants and were similar in leaf area to those of the $2.0 \mathrm{~m} M \mathrm{~N}$ treatment. The average area per leaflet increased linearly with $\mathrm{N}$ input $\left(y=0.82 x+18.9, r^{2}=0.89, p<0.01\right)$, and it was significantly greater in Bradyrhizobium-inoculated than in N-fertilized plants. The increase in the average area per leaflet was enhanced in the presence of VAM. The proportion of secondary to primary leaves increased linearly with solution $\mathrm{N}$ concentration $\left(\mathrm{y}=0.16 \mathrm{x}+0.09, r^{2}=0.96, \mathrm{p}<0.01\right)$ and with nodulation, but was low in the presence of the VAM fungus. Specific leaf area was significantly greater in nodulated plants compared to the $\mathrm{N}$-fertilized plants. Nodulated VAM soybeans had as much leaf area as the $2.0 \mathrm{mMN}$ treatment, although the $\mathrm{N}$-fertilized plants had more leaves and relatively more secondary leaves.

\section{Elemental Composition}

The $\mathrm{N}$ contents of nodulated plants were equivalent to plants that received between 4.0 and $5.0 \mathrm{mM}$ $\mathrm{N}$ (Table 2). The $\mathrm{N}$ concentration of the nodules was more than twice that of the roots and was $30 \%$ greater than the leaf $\mathrm{N}$ levels in nodulated plants. Nodulated VAM soybeans had leaf and nodule $N$ contents similar to the corresponding tissue $\mathrm{N}$ levels for the Pfertilized nodulated plants. There was a differential redistribution of $\mathrm{N}$ in the nodulated plants. Total $\mathrm{N}$ increased linearly with solution $N(y=104 x+97$, $r^{2}=0.98, \mathrm{p}<0.01$ ). Total $\mathrm{N}$ in the leaves of these plants was equivalent to plants that were given between 4.3 and $5.2 \mathrm{mM}$ N while the total $\mathrm{N}$ in roots was equivalent to that of plants that received between 2.8 and $3.8 \mathrm{~m} M \mathrm{~N}$. The seed contributed $25 \pm 5 \mathrm{mg}$ $\mathrm{N}$ in the $-\mathrm{N}$ control $(0.0 \mathrm{~m} M \mathrm{~N}$ treatment $)$; the remaining $100 \mathrm{mg} \mathrm{N}$ was assimilated from soil $\mathrm{N}$. Phosphorus-fertilized soybeans inoculated with Bradyrhizobium assimilated an average of $468 \mathrm{mg} \mathrm{N}$ over the

Table 1. Yields and leaf area parameters for soybean plants grown under various $\mathbf{N}$ and $P$ regimes.

\begin{tabular}{|c|c|c|c|c|c|c|c|}
\hline Treatment & Dry weight & $\begin{array}{c}\text { Shoot/Root } \\
\text { ratio }\end{array}$ & Nodes & $\begin{array}{l}\text { Total leaf } \\
\text { area }\end{array}$ & $\begin{array}{c}\text { Average } \\
\text { area/leaflet }\end{array}$ & $\begin{array}{l}\text { Specific } \\
\text { leaf area }\end{array}$ & $\begin{array}{l}\text { Primary to } \\
\text { secondary leaf } \\
\text { area ratio }\end{array}$ \\
\hline & g plant ${ }^{-1}$ & & Nodes plant-1 & $\mathbf{m}^{2}$ & $\mathrm{~mm}^{2}$ leaf $^{-1}$ & $\mathbf{m}^{2} \mathbf{k g}^{-1}$ & \\
\hline \multicolumn{8}{|l|}{ P-fertilized plants (non-VAM) } \\
\hline $\begin{array}{l}\text { N concentration }(m M) \\
0.0 \\
1.0 \\
2.0 \\
4.0\end{array}$ & $\begin{array}{l}18.1 \\
22.6 \\
27.7 \\
37.8\end{array}$ & $\begin{array}{l}2.43 \\
2.46 \\
2.73 \\
3.40\end{array}$ & $\begin{array}{l}15.5 \\
16.6 \\
17.6 \\
19.2\end{array}$ & $\begin{array}{l}0.122 \\
0.138 \\
0.183 \\
0.344\end{array}$ & $\begin{array}{l}1980 \\
1960 \\
1970 \\
2270\end{array}$ & $\begin{array}{l}20.1 \\
18.1 \\
18.8 \\
26.0\end{array}$ & $\begin{array}{l}0.15 \\
0.20 \\
0.36 \\
0.76\end{array}$ \\
\hline $\begin{array}{l}\text { Bradyrhizobium strains } \\
110 \\
136 \\
61 \mathrm{~A} 118\end{array}$ & $\begin{array}{l}30.7 \mathrm{c} \\
36.5 \mathrm{ab} \\
33.9 \mathrm{~b}\end{array}$ & $\begin{array}{l}3.69 \mathrm{ab} \\
3.90 \mathrm{a} \\
3.32 \mathrm{c}\end{array}$ & $\begin{array}{l}19.0 \mathrm{a} \\
19.1 \mathrm{a} \\
18.8 \mathrm{a}\end{array}$ & $\begin{array}{l}0.312 \mathrm{c} \\
0.393 \mathrm{a} \\
0.361 \mathrm{ab}\end{array}$ & $\begin{array}{l}2970 a \\
3020 a \\
2710 a b\end{array}$ & $\begin{array}{l}29.8 \mathrm{a} \\
31.1 \mathrm{a} \\
27.7 \mathrm{ab}\end{array}$ & $\begin{array}{l}0.57 \mathrm{ab} \\
0.71 \mathrm{a} \\
0.81 \mathrm{a}\end{array}$ \\
\hline \multicolumn{8}{|l|}{ VAM plants (no added P) } \\
\hline $\begin{array}{l}\text { Control (no Bradyrhizobium) } \\
110 \\
136 \\
61 \mathrm{~A} 118\end{array}$ & $\begin{array}{l}12.6 \mathrm{z} \\
18.5 \mathrm{y} \\
19.1 \mathrm{xy} \\
20.6 \mathrm{x}\end{array}$ & $\begin{array}{l}2.42 \mathrm{z} \\
3.54 \mathrm{y} \\
3.60 \mathrm{y} \\
3.33 \mathrm{y}\end{array}$ & $\begin{array}{l}14.8 \mathrm{z} \\
17.9 \mathrm{y} \\
17.7 \mathrm{y} \\
17.6 \mathrm{y}\end{array}$ & $\begin{array}{l}0.096 \mathrm{z} \\
0.169 \mathrm{y} \\
0.188 \mathrm{y} \\
0.186 \mathrm{y}\end{array}$ & $\begin{array}{l}2080 \mathrm{z} \\
3990 \mathrm{y} \\
4010 \mathrm{y} \\
3470 \mathrm{y}\end{array}$ & $\begin{array}{l}21.5 \mathrm{z} \\
29.4 \mathrm{xy} \\
32.4 \mathrm{y} \\
28.1 \mathrm{x}\end{array}$ & $\begin{array}{l}0.01 \mathrm{z} \\
0.10 \mathrm{yz} \\
0.20 \mathrm{y} \\
0.11 \mathrm{yz}\end{array}$ \\
\hline
\end{tabular}

- Mean values ( 6 replications) for each parameter having common letters within a column are not significantly different at the 0.05 level by Duncan's Multiple Range Test (DMRT). 
seed and the soil contribution (Table 2). The total $\mathrm{N}$ input of $189 \mathrm{mg} \mathrm{N}$ by Bradyrhizobium in VAM associations represented a $40 \%$ decrease relative to the amount of $\mathrm{N}$ taken up by $\mathrm{P}$-fertilized, nodulated soybeans.

Leaf $P$ concentrations for nodulated soybeans were significantly greater than for any $\mathrm{N}$-fertilized plants (Table 2). Nodule and root $P$ contents were similar for non-VAM plants, but in VAM plants nodule $P$ content was three times higher than root $P$ contents. Nodulated VAM soybeans had markedly lower leaf and root $P$ contents than the P-fertilized plants. Total $\mathrm{P}$ did not show a good linear increase with $\mathrm{N}$ fertilization $\left(\mathrm{y}=3.4 \mathrm{x}+51, r^{2}=0.51, \mathrm{p}>0.05\right)$. Total $P$ uptake in plants inoculated with Bradyrhizobium was equivalent to plants that were given between 4.2 and $5.4 \mathrm{mM} \mathrm{N}$ (Table 2). The N-limited VAM control took up $10 \mathrm{mg} P$ in excess of the $2 \mathrm{mg} \mathrm{P}$ in the seed, while nodulated VAM plants assimilated approximately $13 \mathrm{mg} \mathrm{P}$.
The uptake of micronutrients was modified by the presence of both microsymbionts (Table 3 ). Root Fe content was higher in nodulated VAM plants than in non-VAM plants, while the Fe content of the leaves was lower. Nodule Fe content was higher than in either roots or leaves. Nodulated roots had higher Mn contents than non-nodulated roots, but shoot $\mathrm{Mn}$ in nodulated VAM plants was lower than non-VAM plants. Nodulation did not affect $\mathrm{Zn}$ concentration in roots but lowered the concentration of $\mathrm{Zn}$ in the leaves. Mycorrhizal plants had higher $\mathrm{Zn}$ and $\mathrm{Cu}$ concentrations than non-VAM plants. Copper concentrations were generally lower in the leaves of nodulated plants compared to leaves from non-nodulated plants.

\section{Nodulation and Nitrogenase Activity}

Inoculation of non-VAM plants with strains 136 and $61 \mathrm{~A} 118$ resulted in greater nodule dry weights than inoculation with strain 110 (Table 4). Acetylene-

Table 2. Elemental composition for soybean plants grown under various $\mathbf{N}$ and $\mathrm{P}$ regimes.

\begin{tabular}{|c|c|c|c|c|c|c|c|c|}
\hline \multirow[b]{2}{*}{ Treatment } & \multicolumn{3}{|c|}{$\mathbf{N}$ content } & \multirow[b]{2}{*}{ Total N } & \multicolumn{3}{|c|}{$P$ content } & \multirow[b]{2}{*}{ Total P } \\
\hline & Leaf & Root & Nodule & & Leaf & Root & Nodule & \\
\hline & 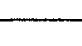 & $\mathbf{m g} \mathbf{g}^{-1}$ & 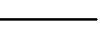 & mg plant ${ }^{-1}$ & 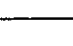 & $\mathbf{m} \mathbf{g}^{\mathbf{g}^{-1}}$ & & mg P plant ${ }^{-1}$ \\
\hline \multicolumn{9}{|c|}{ P fertilized plents (non-VAM) } \\
\hline $\begin{array}{c}\text { N concentre } \\
0.0 \\
1.0 \\
2.0 \\
4.0\end{array}$ & $\begin{array}{l}8 d \\
10 d \\
14 c \\
26 b\end{array}$ & $\begin{array}{l}14 \\
15 \\
17 \\
20\end{array}$ & $\begin{array}{l}\text { ND } \dagger \\
\text { ND } \\
\text { ND } \\
\text { ND }\end{array}$ & $\begin{array}{l}126 \\
179 \\
278 \\
530\end{array}$ & $\begin{array}{l}3.3 \\
2.9 \\
2.5 \\
2.8\end{array}$ & $\begin{array}{l}7.0 \\
4.8 \\
3.6 \\
4.1\end{array}$ & $\begin{array}{l}\text { ND }+ \\
\text { ND } \\
\text { ND } \\
\text { ND }\end{array}$ & $\begin{array}{l}55.6 \\
53.0 \\
58.5 \\
71.3\end{array}$ \\
\hline $\begin{array}{c}\text { Bradyrhizo } \\
110 \\
136 \\
61 \mathrm{~A} 118\end{array}$ & $\begin{array}{l}35 a^{*} \\
36 a \\
32 a\end{array}$ & $\begin{array}{l}20 a \\
21 a \\
21 a\end{array}$ & $\begin{array}{l}48 a \\
47 a \\
44 b\end{array}$ & $\begin{array}{l}543 \text { b } y \\
647 \text { a } \\
593 \text { ab yz }\end{array}$ & $\begin{array}{l}5.2 \mathrm{a} \\
3.9 \mathrm{~b} \\
4.7 \mathrm{a}\end{array}$ & $\begin{array}{l}3.5 \mathrm{~cd} \\
4.2 \mathrm{bc} \\
3.3 \mathrm{~d}\end{array}$ & $\begin{array}{l}3.4 \mathrm{~b} \\
4.0 \mathrm{a} \\
3.5 \mathrm{~b}\end{array}$ & $\begin{array}{l}81.8 \mathrm{ab} w \mathrm{x} \\
82.3 \mathrm{ab} w \mathrm{x} \\
86.2 \mathrm{a} \mathrm{w}\end{array}$ \\
\hline \multicolumn{9}{|c|}{ VAM plants (no added P) } \\
\hline $\begin{array}{l}\text { Control } \\
110 \\
136 \\
61 \mathrm{~A} 118\end{array}$ & $\begin{array}{r}9 \mathrm{z} \\
30 \mathrm{x} \\
31 \mathrm{x} \\
27 \mathrm{y}\end{array}$ & $\begin{array}{l}14 z \\
20 y \\
18 y \\
19 y\end{array}$ & $\begin{array}{l}\text { ND } \dagger \\
44 y \\
47 x \\
42 y\end{array}$ & $\begin{array}{r}93 w \\
276 x \\
279 x \\
290 x\end{array}$ & $\begin{array}{l}1.2 \mathrm{z} \\
1.6 \mathrm{y} \\
1.8 \mathrm{y} \\
1.3 \mathrm{z}\end{array}$ & $\begin{array}{l}1.7 \mathrm{y} \\
1.2 \mathrm{z} \\
1.1 \mathrm{z} \\
1.0 \mathrm{z}\end{array}$ & $\begin{array}{l}\mathrm{ND} \dagger \\
2.9 \mathrm{y} \\
3.4 \mathrm{x} \\
2.8 \mathrm{y}\end{array}$ & $\begin{array}{l}12.4 \mathrm{z} \\
14.8 \mathrm{y} \\
16.4 \mathrm{y} \\
15.0 \mathrm{y}\end{array}$ \\
\hline
\end{tabular}

* Mean values for each parameter having common letters within a column are not significantly different at the 0.05 level by DMRT.

$\dagger$ Plant provided with $\mathrm{NH}_{4} \mathrm{NO}_{3}$ were not inoculated and formed no nodules.

Table 3. Micronutrient content for plant parts from soybean plants grown under various $\mathbf{N}$ and $\mathrm{P}$ regimes.

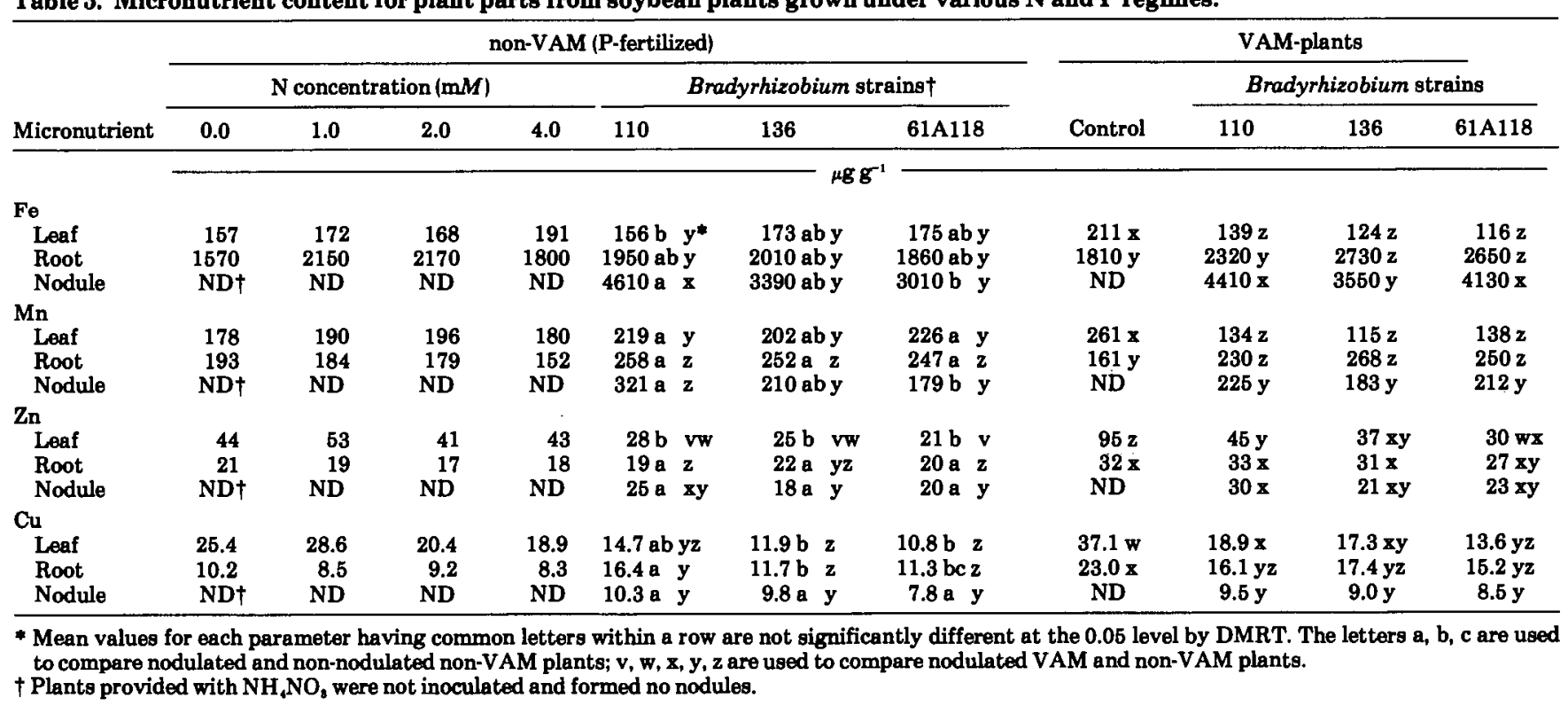


Table 4. Symbiotic $\mathbf{N}_{\mathbf{2}}$ fixation parameters for soybean plants inoculated with Bradyrhizobium strains, or infected with both VAM fungi and inoculated with Bradyrhizobium.

\begin{tabular}{|c|c|c|c|c|}
\hline $\begin{array}{c}\text { Rhizobium } \\
\text { strains }\end{array}$ & $\begin{array}{c}\text { Nodule } \\
\text { dry weight }\end{array}$ & $\underset{\text { produced }}{\mathrm{C}_{\mathbf{8}} \mathrm{H}_{4}}$ & $\begin{array}{c}\mathbf{H}_{2} \\
\text { evolved }\end{array}$ & $\underset{\mathbf{N} \dagger}{\text { Symbiotic }}$ \\
\hline & g plant ${ }^{-1}$ & \multicolumn{2}{|c|}{$-\mu \mathrm{mol} \mathrm{plant}^{-1} \mathbf{h}^{-1}-$} & $\mathrm{mg} \mathrm{plant}^{-1}$ \\
\hline \multicolumn{5}{|c|}{$P$ fertilized (non-VAM) } \\
\hline $\begin{array}{l}110 \\
136 \\
61 \mathrm{~A} 118\end{array}$ & $\begin{array}{l}0.63 b^{*} \\
0.85 a \\
0.82 a\end{array}$ & $\begin{array}{l}18.3 b \\
42.6 a \\
22.5 b\end{array}$ & $\begin{array}{l}0.72 \mathrm{c} \\
0.47 \mathrm{c} \\
5.33 \mathrm{a}\end{array}$ & $\begin{array}{l}417 b c \\
520 a \\
467 a b\end{array}$ \\
\hline \multicolumn{5}{|c|}{ VAM plants (no added P) } \\
\hline $\begin{array}{l}\text { Control } \\
110 \\
136 \\
61 \mathrm{~A} 118\end{array}$ & $\begin{array}{l}0.39 \mathrm{c} \\
0.41 \mathrm{c} \\
0.42 \mathrm{c}\end{array}$ & $\begin{array}{r}8.1 \mathrm{~d} \\
16.6 \mathrm{c} \\
7.9 \mathrm{~d}\end{array}$ & $\begin{array}{l}0.16 \mathrm{~d} \\
0.03 \mathrm{~d} \\
1.65 \mathrm{~b}\end{array}$ & $\begin{array}{l}175 \mathrm{~d} \\
182 \mathrm{~d} \\
197 \mathrm{~d}\end{array}$ \\
\hline
\end{tabular}

- Mean values for each parameter having common letters within a column are not significantly different at the 0.05 level by DMRT.

† Symbiotic $\mathbf{N}=$ Total $\mathbf{N}-($ seed $\mathbf{N}+$ assimilated soil $\mathbf{N})$.

dependent $\mathrm{C}_{2} \mathrm{H}_{4}$ production was significantly higher in roots colonized with strain 136 , whereas $\mathrm{H}_{2}$ evolution was significantly greater for nodules colonized by strain $61 \mathrm{~A} 118$ regardless of the $P$ source (Table 4). Acetylene reduction and symbiotic $N$ (total $N$ less seed $\mathrm{N}$ and assimilated soil $\mathrm{N}$ ) were correlated in nonVAM plants $(r=0.83, \mathrm{p}<0.05)$ and in VAM plants $(r=0.73, \mathrm{p}<0.05)$.

\section{Fungal Colonization}

Inoculation of soybean plants with $G$. fasciculatum resulted in over $40 \%$ colonization of all VAM-plant roots (Table 5). Soybeans nodulated with strains 136 and $61 \mathrm{Al18}$ had significantly higher fungal colonization that the VAM controls or plants inoculated with strain 110 . Inoculation with strain $61 \mathrm{~A} 118 \mathrm{re}$ sulted in the largest amount of fungal proliferation in terms of VAM-fungal biomass. Bradyrhizobium strain $61 \mathrm{~A} 118$ thus had the greatest effect in stimulating VAM-fungal growth, and hosts infected with this strain had the highest VAM biomass to nodule weight ratio (Table 5).

\section{DISCUSSION}

The effects of beneficial microsymbionts on their host plants have been traditionally studied in terms of biomass or yield enhancement $(20,22)$ or by determining the activity of an individual process such as $\mathrm{C}_{2} \mathrm{H}_{2}$ reduction (30), with nutrient-deficient controls serving as the non-symbiotic plants. While nutritional equivalency may be achieved by supplementing controls with $\mathrm{N}$ and $\mathrm{P}$, host responses to nodulation (26) or VAM fungal colonization (5) will be lacking. Such host-responses were noted in the divergence in $\mathrm{N}$ utilization and storage (see also 25), leaf development, shoot to root ratio, and the allocation of nutrients to the leaves. This finding indicates that the supply-demand relationships in these symbiotic plants are necessarily different from the $\mathrm{N}$ and $P$ fertilized plants. Dry weight $N$ concentration can vary according to the efficiency of the $\mathrm{N}_{2}$-fixing symbiosis (12) or the additional respiratory burden associated with $\mathrm{N}_{2}$ fixation in nodulated plants (28). These differences may affect such essential physiological processes as photosynthetic activity $(10)$, the utilization of carbohydrates by the endophytes $(3,11)$
Table 5. Fungal characteristics for soybean roots colonized with VAM fungi and inoculated with $R$ hizobium.

\begin{tabular}{lcccc}
\hline Treatment & $\begin{array}{c}\text { VAM-fungal } \\
\text { colonization }\end{array}$ & $\begin{array}{c}\text { Intradical VAM- } \\
\text { fungal biomass }\end{array}$ & $\begin{array}{c}\text { \% Fungal } \\
\text { biomass }\end{array}$ & $\begin{array}{c}\text { VAM/Nodule } \\
\text { ratio } \dagger\end{array}$ \\
\hline & $\%$ & mg plant $^{-1}$ & $\%$ & \\
Control & $42.0 \mathrm{c}^{*}$ & $195 \mathrm{c}$ & $5.2 \mathrm{c}$ & $0.0 \mathrm{~d}$ \\
110 & $43.6 \mathrm{c}$ & $207 \mathrm{c}$ & $5.6 \mathrm{c}$ & $0.54 \mathrm{c}$ \\
136 & $56.8 \mathrm{~b}$ & $267 \mathrm{~b}$ & $7.0 \mathrm{~b}$ & $0.68 \mathrm{~b}$ \\
$61 \mathrm{~A} 118$ & $62.9 \mathrm{a}$ & $350 \mathrm{a}$ & $7.7 \mathrm{a}$ & $0.84 \mathrm{a}$ \\
\hline
\end{tabular}

* Means having common letters within a column are not significantly different at the 0.05 level by DMRT.

† VAM-fungal biomass (mg)/nodule weight (mg).

and compensatory $\mathrm{CO}_{2}$ fixation in response to the additional demand by the endophytes (15).

Colonization by one or both of the two endophytes altered the uptake and distribution of several micronutrients in the host plant. The decreased $\mathrm{Mn}$ uptake by VAM plants is of interest since acid soils often contain phytotoxic levels of $\mathrm{Mn}$ and $\mathrm{Al}$ that can be detrimental to $\mathrm{N}_{2}$ fixation (13) or the growth of most Rhizobium strains (14). Plants inoculated with $B$. japonicum increased Mn uptake to toxic levels (21), but dual colonization by Bradyrhizobium and the VAM fungus decreased $\mathrm{Mn}$ to less than critical concentrations. Low concentrations of available Mn could be expected in VAM hyphae or vesicles since Fe or $\mathrm{Mn}$ is inactivated through the precipitation with phosphates (18). It was uncertain whether the increases in $\mathrm{Cu}$ and $\mathrm{Zn}$ concentrations were the result of higher requirements for these elements by the VAM symbiosis, or if accumulation was incidental to the greater uptake capability of the fungus. The enhanced $\mathrm{Cu}$ and $\mathrm{Zn}$ uptake did not appear related to $\mathrm{N}_{2}$ fixation since the levels of these micronutrients were lower in nodule than in root.

Nodule dry weights were a function of $P$ availability and to some extent $B$. japonicum strain differences (17). As P fertilization increased, nodule weights doubled, but nodule activity increased only $20 \%$. It was concluded that nodule growth, rather than nitrogenase activity responded to the increase in $P$ availability. The dependence of nodulation on the VAM fungus in tripartite associations was shown by the approximately 3 -fold increase in nodule $P$ over root $\mathrm{P}$ concentrations as compared to no difference in the P-fertilized non-VAM plants. The nodule appears to be a powerful sink for $\mathrm{P}$ (and $\mathrm{Fe}$ ) whose requirements tend to be satisfied even under limiting conditions (31). Hydrogen evolution relative to $\mathrm{C}_{2} \mathrm{H}_{2}$ reduction was not affected by VAM-colonization, so there was no change in net $\mathrm{N}_{2}$ fixation as has been noted in Phaseolus-Rhizobium-Glomus symbiosis (4).

The improved growth and $\mathrm{N}$ nutrition in these tripartite associations may have been due to VAMmediated host effects, rather than improved nodulation or $\mathrm{N}_{2}$ fixation. Strain $61 \mathrm{~A} 118$ was least efficient at $\mathrm{N}_{2}$ fixation (greatest $\mathrm{H}_{2}$ evolution), but this strain stimulated $P$ uptake in non-VAM plants and also the greatest proliferation of the VAM fungus. Differences between strains of $B$. japonicum in phosphate storage and utilization (7) probably plays a role in the host response. Rapid colonization by a VAM fungus would result in an enhanced P status, but would lower the level of carbohydrate in the roots. Brady- 
rhizobium strains unable to store $\mathrm{P}$ but capable of storing $\mathrm{C}$ as poly- $\beta$-hydroxybutyric acid could have a competitive advantage under these conditions.

These data demonstrate that several morphological and nutritional differences occur in response to the minerals and microsymbionts to which a plant is exposed. The measurement of these attributes in the field should allow further identification of factors influencing these symbioses and would allow correlation of the data with more detailed laboratory results.

\section{REFERENCES}

1. Barea, J.M., and C. Azcón-Aguilar. 1982. Production of plant growth-regulating substances by the vesicular-arbuscular mycorrhizal fungus Glomus mosseae. Appl. Environ. Microbiol. 43:810-813.

2. Barr, A.J., J.H. Goodnight, J.P. Sall, and J.T. Helwig. 1982. A user's guide to SAS 82. SAS Institute, Inc., Raleigh, NC.

3. Bethlenfalvay, G.J., and R.S. Pacovsky. 1983. Light effects in mycorrhizal soybeans. Plant Physiol. 73:969-972.

4. ---, R.S. Pacovsky, H.G. Bayne, and A.E. Stafford. 1982. Interactions between nitrogen fixation, mycorrhizal colonization, and host plant growth in the Phaseolus-Rhizobium-Glomus symbiosis. Plant Physiol. 70:446-450.

5. Bowen, G.D. 1978. Dysfunction and shortfalls in symbiotic responses. p. 231-256. In J.G. Horsfall and E.D. Cowling (ed.), Plant disease. Vol. III. Academic Press, New York.

6. Carling, D.E., W.G. Riehle, M.F. Brown, and D.R. Johnson. 1978. Effects of a vesicular-arbuscular mycorrhizal fungus on nitrate reductase and nitrogenase activities in nodulating and non-nodulating soybeans. Phytopathology 68:1590-1596.

7. Cassman, K.G., D.N. Munns, and D.P. Beck. 1981. Phosphorus nutrition of Rhizobium japonicum: Strain differences in phosphate storage and utilization. Soil Sci. Soc. Am. J. 45:517520.

8. Crush, J.R. 1974. Plant growth responses to vesicular-arbuscular mycorrhiza. VII. Growth and nodulation of some herbage legumes. New Phytol. 73:743-749.

9. Daft, M.S. 1978. Nitrogen fixation in nodulated and mycorrhizal crop plants. Ann. Appl. Biol. 88:461-462.

10. de Mooy, C.J., J. Pesek, and E. Spaldon. 1973. Mineral nutrition. In B.E. Caldwell (ed.) Soybeans: Improvement, production and uses. 16:267-352.

11. Gates, C.T., and W.J. Muller. 1979. Nodule and plant development in soybean: Growth response to nitrogen, phosphorus and sulfur. Aust. J. Bot. 27:203-215.

12. Haydock, K.P., D.O. Norris, and T.L. Mannetje. 1980. The relation between nitrogen percent and dry weight in inoculated legumes. Plant Soil 57:353-362.

13. Holding, A.J., and J.F. Lowe. 1971. Some effects of acidity and heavy metals on the Rhizobium-leguminous plant association. Plant Soil Spec. Vol. 1971:153-166.

14. Keyser, H.H., and D.N. Munns. 1979. Effects of calcium, manganese and aluminum on the growth of Rhizobia in acid media.
Soil Sci. Soc. Am. J. 43:500-503.

15. Kucey, R.M.N., and E.A. Paul. 1982. Carbon flow, photosynthesis, and $\mathrm{N}_{\mathbf{2}}$ fixation in mycorrhizal and nodulated faba beans. Soil Biol. Biochem. 14:401-405.

16. Lawn, R.J., and W.A. Brun. 1974. Symbiotic nitrogen fixation in soybeans. I. Effect of photosynthetic source-sink manipulations. Crop Sci. 14:11-16.

17. Mosse, B., C.L. Powell, and D.S. Hayman. 1976. Plant growth responses to vesicular-arbuscular mycorrhiza. IX. Interactions between VA mycorrhiza, rock phosphate and symbiotic nitrogen fixation. New Phytol. 70:331-342.

18. Murphy, L.S., R. Ellis, Jr., and D.C. Adriano. 1981. Phosphorus-micronutrient interaction effects on crop production. J. Plant Nutr. 3:593-613.

19. Nutman, P.S. 1954. Symbiotic effectiveness in nodulated red clover 1. Variation in host and bacteria. Heredity 8:35-46.

20. O'Bannon, J.H., D.W. Evans, and R.N. Peaden. 1980. Alfalfa varietal response to seven isolates of vesicular-arbuscular mycorrhizal fungi. Can. J. Plant Sci. 60:859-863.

21. Ohki, K. 1981. Manganese critical levels for soybean growth and physiological processes. J. Plant Nutr. 3:271-284.

22. Pacovsky, R.S., H.G. Bayne, and G.J. Bethlenfalvay. 1984. Symbiotic interactions between strains of Rhizobium phaseoli and cultivars of Phaseolus vulgaris L. Crop Sci. 24:101-105.

23. ---, G.J. Bethlenfalvay, and E.A. Paul. 1986. Comparisons between phosphorus-fertilized and mycorrhizal plants. Crop Sci. 26:151-156.

24. Pate, J.S. 1977. Functional biology of dinitrogen fixation by legumes. p. 374-517. In R.S.W. Hardy, and W.S. Silver (eds.) A treatize on dinitrogen fixation. Section III. John Wiley and Sons, New York.

25. --, C.A. Atkins, K. Hamel, D.L. McNeil, and D.B. Layzell. 1979. Transport of organic solutes in phloem and xylem of a nodulated legume. Plant Physiol. 63:1082-1088.

26. Puppo, A., and J. Rigaud. 1978. Cytokinis and morphological aspects of french-bean roots in the presence of Rhizobium. Physiol. Plant 42:202-206.

27. Redente, E.F., and F.B. Reeves. 1981. Interaction between vesicular-arbuscular mycorrhiza and Rhizobium and their effect on sweetvetch growth. Soil Sci. 12:410-415.

28. Ryle, G.J.A., C.E. Powell, and A.J. Gordon. 1978. The respiratory costs of nitrogen fixation in soybean, cowpea, and white clover 11. Comparisons of the cost of nitrogen fixation and the utilization of combined nitrogen. J. Exp. Bot. 30:145153.

29. Smith, S.E., D.J.D. Nicholas, and F.A. Smith. 1979. Effect of early mycorrhizal infection on nodulation and nitrogen fixation in Trifolium subterraneum L. Aust. J. Plant Physiol. 6:305316.

30. Smith, S.E., and M.J. Daft. 1977. Interactions between growth, phosphate content and nitrogen fixation in mycorrhizal and non-mycorrhizal Medicago sativa. Aust. J. Plant Physiol. 4:403413.

31. Van Schreven, D.A. 1958. Some factors affecting the uptake of nitrogen by legumes. p. 137. In E.G. Hallsworth (ed.) Nutrition of the legumes. Butterworths, London.

32. Zelitch, I. 1975. Improving the efficiency of photosynthesis. Science 188:626-633. 